\title{
The Effect of Company Size, Financial Performance, and Corporate Governance on the Disclosure of Sustainability Report
}

\author{
Indrianingsih *1 and Linda Agustina ${ }^{2}$ \\ 1,2 Accounting Department, Faculty of Economics, Universitas Negeri Semarang
}

\begin{abstract}
ARTICLE INFO
\section{Article History:}

Received July $2^{\text {th }}, 2019$

Accepted June 30 ${ }^{\text {th }}, 2020$

Available July $30^{\text {th }}, 2020$

\section{Keywords:}

sustainability report; company size; profitability; leverage; liquidity; company activities, board of directors; independent commissioners; audit committee

ABSTRACT

The purpose of this research is to analyze the effect of company size, profitability, leverage, liquidity, company activities, board directors, independent commissioners, and audit committee on sustainability report disclosure. The population of this research was non-financial companies listed on the IDX in 2013-2017 as many as 483 companies. The sample was selected using purposive sampling technique and obtained 17 samples with 5 years of observation so there were 85 units of analysis. Data collection technique used documentation technique. The analysis tool to test hypothesis was multiple linear regression analysis. The results show that variables of liquidity and audit committee have a positive effect on the sustainability report disclosure. Leverage has a negative effect on sustainability report disclosure. Meanwhile, company size, profitability, company activities, board of directors, and independent commissioners do not affect on sustainability report disclosure. The conclusion in this research is variables of leverage, liquidity, and audit committee can provide an important role in sustainability report disclosure. The suggestion for the next researcher is to pay attention to the calculation of corporate ratio, whether using net sales or gross sales.
\end{abstract}

(C) 2020 Published by UNNES. This is an open access article under the CC BY license (http://creativecommons.org/licenses/by/4.0/)

\section{INTRODUCTION}

Along with the development of the concept of sustainable development, profits that are at first corporate main focus began to be balanced with attention to social and environmental aspects. This is according to the Triple Bottom Line idea (Elkington, 1997). This idea is the basis for sustainability reporting.

Sustainability report is defined as a report related to economic, environmental, and social actions on the activities carried out by companies. Through sustainability reports, the implementation of social activities as well as corporate environment is transparently conveyed to stakeholders and society. Reference in the reporting of sustainability report is published by Global Reporting Initiative (GRI).

The absence of clear regulations results in the disclosure of sustainability reports being free, that is, may publish or not. According to Diono \& Prabowo (2017) the average sustainability report disclosure in the companies listed in IDX 2013-2015 is 0.32. Next Sinaga \& Fachrurrozie (2017) stated that LQ45 companies in

\footnotetext{
*E-mail: indrisyafan@gmai.com

_Address: L2 Building 2nd floor, Campus Sekaran, Gunungpati, Semarang, Indonesia, 50229
}

2013-2016 have an average sustainability report disclosure of 0.37 . Based on the results of the study, it can be seen that the sustainability report is low. According to Dilling (2010) one of the causes of low disclosure is the absence of single definition sustainability report that can be accepted by all groups.

There are many factors that affect the disclosure of sustainability reports, namely company size, profitability, leverage, liquidity, company activities, board of directors, independent commissioners, and audit committee that have been widely studied, but give inconsistent results. This can be seen in studies conducted by Dilling (2010), Yi \& Yu (2010), Branco et al. (2014), Nasir et al. (2014), Artiach et al. (2010), Saputro et al. (2013), Syed \& Butt (2017), Idah (2013), Nazari et al. (2015), Shamil et al. (2012), Michelon \& Parbonetti (2015), Sari \& Marsono (2013), Isa (2014), and Bhatia \& Tuli (2016). The existence of gap phenomena and inconsistent results among several studies is the background of this study.

This study has the aim of analyzing company size, profitability, leverage, liquidity, company activities, board of directors, independent commissioners, and audit committee related to their influence on the sustainability report disclosure. The originality of this study 
is the use of the latest measurement standards namely GRI Standards to measure sustainability reports. There are things that distinguish GRI Standards from the previous version is there are significant changes in terms of document structure and language use in GRI Standards. In addition, the items disclosed at GRI Standards are 77 items, while on GRI G4 there are 91 items.

This study is based on three theories namely stakeholder theory, legitimacy theory, and agency theory. First, in making decisions, stakeholders need information about the company, including sustainability reports. This is same with Ghozali \& Chariri (2007) who explained that company must work for the benefit of all parties so that it is expected to provide information for stakeholders.

Second, Suchman (1995) explained legitimacy is an equalization of understanding of norms that companies believe with norms that develop in society. The way to gain legitimacy from the public is through sustainability reports. Third, agency theory interprets the relationship between principal (shareholder) and agent (management). According to Eisenhardt (1989) there is a conflict of interest between principal and agent caused by the assumption that humans essentially prioritize themselves first. Effort to minimize this conflict of interest is through aligning various company interests through a monitoring mechanism. Thus, a good corporate governance can be formed which encourages broad disclosure of information including disclosure of sustainability reports.

Company size is defined as a large or small measuring instrument of a company. Large-sized company is potentially greater in damaging the environment and having more stakeholders (Burgwal \& Vieira, 2014). In addition, more ability to fulfil its responsibilities reveals a wider Environmental Reporting also owned by large companies (Liu \& Anbumozhi, 2009). Referring to the legitimacy theory, the disclosure of sustainability information that is in line with the social rules that run in the community is needed to maintain the legitimacy of the company. Thus, the company is able to show to the public that the company has operated the business responsibly and improve the company's image to the community. This is line with Idah (2013), Branco et al. (2014), and Bhatia \& Tuli (2016) stated that sustainability reports can be positively influenced by company size.

\section{$\mathrm{H}_{1}$ : Company Size has a Positive Effect on Sustain- ability Report Disclosures}

The maximum profit is a target to be achieved by a company. The ability of companies to get profits can be measured using profitability ratio. The strong position of corporate finances can be seen in high profitability ratio. In line with stakeholder theory, a strong financial position will foster confidence in providing information to stakeholders. This includes the disclosure of sustainability reports that present social activities have been carried out by the company. Thus, when the value of profitability is high in a company, it can encourage the disclosure of sustainability reports. This is in line with
Dilling (2010), Yi \& Yu (2010), and Branco et al. (2014) who proved that sustainability report can be positively influenced by profitability.

\section{$\mathrm{H}_{2}$ : Profitability Has a Positive Effect on Sustain- ability Report Disclosure}

Capital is one of the factors in financing a company's operations, which can come from own funds or loans. How much corporate activities are financed by loans can be calculated using a leverage ratio (Kasmir, 2015). High leverage shows that the use of debt as a source of corporate funding is high as well, so that the company gets a big push from creditors to complete their loans (Ferrao et al., 2016). This causes companies tend to prioritize loan repayments rather than to make voluntary disclosures including social responsibility. Stakeholder theory states that high corporate leverage later will make the interests of stakeholders not properly considered, including the interest in providing company information widely. This is in line with Nasir et al. (2014) and Artiach et al. (2010) who proved that sustainability report can be negatively affected by leverage.

\section{$\mathrm{H}_{3}$ : Leverage Has a Negative Effect on Sustainabil- ity Report Disclosure}

Corporate expertise in providing payment of debts that are due can be calculated using a liquidity ratio (Kasmir, 2015). High liquidity symbolizes corporate expertise in paying short-term debt in accordance with the specified time so as to indicate the strong position of corporate finances. Referring to stakeholder theory, the positive image of a company and the acquisition of support from stakeholders can be formed through the disclosure of information needed by stakeholders, for example disclosure of sustainability reports. This method is generally carried out by companies that have a strong financial position, so it can be known that sustainability reports can be driven its disclosure by high liquidity. This is in line with Saputro et al. (2013) and Syed \& Butt (2017) who stated the sustainability report can be positively influenced by liquidity.

\section{$\mathrm{H}_{4}$ : Liquidity has a Positive Effect on the Sustain- ability Report Disclosure}

Economic resources (assets) that companies have are expected to be useful for business continuity. In using its assets the company must be effective, which can be measured using the ratio of company activity (Kasmir, 2015). High value of ratio explains that company is effective in controlling its assets, so that with this situation, a strong financial position will be achieved by the company. According to stakeholder theory, the company can reveal that the operational activities carried out by the company do not neglect the impacts caused through the disclosure of sustainability report. This method is generally carried out by companies that have a strong financial position, so that it can be known that sustainability reports can be encouraged its disclosure by high activity ratio. This is in line with Vitezi $\square$ et al. (2012) and Wulanda (2017) who stated sustainability reports can be positively influenced by company activities. 


\section{$\mathrm{H}_{5}$ : Company Activities Have Positive Effect on Sustainability Report Disclosure}

The implementation of Good Corporate Governance (GCG) in its implementation relies heavily on the board of directors who are relied on in managing the company. Board of directors is obliged to inform the overall company activities to stakeholders which aim in order to the company keeps getting support so that business sustainability is created. Coordination between boards of directors is carried out through a meeting of the board of directors' members. Stakeholder theory explains high frequency of meetings between boards of directors signalling good cooperation. This is able to facilitate the realization of GCG, so that the board of directors is considered capable of publishing corporate social activities through sustainability report disclosure. This is in line with Idah (2013), Nazari et al. (2015), and Shamil et al. (2012) that proved the sustainability report can be positively influenced by the board of directors proxied by many meetings.

\section{$\mathrm{H}_{6}$ : Board of Directors Has Positive Effects on Sus- tainability Report Disclosure}

Referring to agency theory, between principals (management) and agents (shareholders) can raise conflicts of interest. Thus, an independent commissioner is needed to supervise management behaviour so that it is aligned with the needs company and shareholders. Moreover, management does not have opportunity to take opportunistic actions such as earnings management. This is needed because there is no independent commissioner relationship between management and stakeholders. Therefore, the better the independent commissioner in conducting supervision to management can suppress the disclosure of broad company information for example sustainability report. Diono \& Prabowo (2017) and Michelon \& Parbonetti (2012) explained the sustainability report can be positively influenced by an independent commissioner.

\section{$\mathrm{H}_{7}$ : Independent Commissioner Has Positive Effect on Sustainability Report Disclosure}

Audit committee is created to ease the work of the board of commissioners (Peraturan OJK No. 55/
PJOK.04/2015). Agency theory states the presence of an audit committee can be a powerful instrument in smoothing corporate control. Meetings required by audit committee when carrying out their duties, the higher the frequency of meetings can create good communication and coordination between members regarding decisions taken for the interests of stakeholders. One of them is the decision to disclosure social responsibility, so that it can increase the possibility to disclose the sustainability report. In line with Sari \& Marsono (2013) and Michelon \& Parbonetti (2012) who stated sustainability report can be positively influenced by audit committee as measured by many meetings.

\section{$\mathrm{H}_{8}$ : Audit Committee Has Positive Impact on Sus- tainability Report Disclosure}

\section{RESEARCH METHODS}

This research was a quantitative study using secondary data. Non-financial companies listed in the IDX in 2013-2017 were the population in this study. Purposive sampling was used as a technique for taking samples using the criteria shown in Table 1. A summary of the operational variables used in this study is shown in Table 2.

Documentation technique was made as a data collection technique in the form of annual reports and sustainability reports of all non-financial companies listed on the IDX in 2013-2017. Descriptive statistical analysis and inferential statistical analysis are used as data analysis techniques. Inferential statistical analysis using multiple regression, previously, it is conducted a classical assumption test using IBM SPSS for windows version 23.0. The research pattern is seen in Equation 1.

$$
\begin{aligned}
\text { SDRI }= & \text { C }+\beta_{1} \text { SIZE }+\beta_{2} \text { ROA }+\beta_{3} \text { DER }+\beta 4 C R+ \\
& \beta_{5} \text { TATO }+\beta_{6} \text { DD }+\beta_{7} \text { KI }+\beta_{8} \text { KOMDIT }+ \text { e } \ldots .(1)
\end{aligned}
$$

\section{RESULTS AND DISCUSSIONS}

Descriptive statistical analysis in this study includes the minimum, maximum, average, and standard deviation values. By doing descriptive statistical analysis, we can know the variable description. The results are seen in Table 3.

\begin{tabular}{|c|c|c|c|}
\hline No & Sample Criteria & $\begin{array}{l}\text { Violating } \\
\text { Criteria }\end{array}$ & $\begin{array}{l}\text { Including } \\
\text { Criteria }\end{array}$ \\
\hline & Population & & 483 \\
\hline 1 & $\begin{array}{l}\text { All non-financial companies that published annual reports in 2013-2017 } \\
\text { continuously. }\end{array}$ & (72) & 411 \\
\hline 2 & $\begin{array}{l}\text { Companies publish sustainability reports continuously in } 2013-2017 \text { by using the } \\
\text { Global Reporting Initiative (GRI) guidelines, revealing the GRI standards used, } \\
\text { and including the GRI index. }\end{array}$ & $(394)$ & 17 \\
\hline \multirow[t]{3}{*}{3} & Companies that provide complete information related to research variables. & - & 17 \\
\hline & Observation year & & 5 \\
\hline & Total analysis units & & 85 \\
\hline
\end{tabular}

Table 1. Sample Selection Criteria 
Table 2. Operational Definition of Variables

\begin{tabular}{|c|c|c|}
\hline Name of variables & Definition & Measurements/Indicators \\
\hline Sustainability & Reports related to economic, environmental & $\sum$ item disclosed \\
\hline Report (SRDI) & $\begin{array}{l}\text { and social activities on the activities carried out } \\
\text { by the company (GRI, 2016) }\end{array}$ & $\begin{array}{c}\sum \text { item of GRI Standard Disclosure(77) } \\
\text { (GRI, 2016) }\end{array}$ \\
\hline $\begin{array}{l}\text { Company size } \\
\text { (SIZE) }\end{array}$ & $\begin{array}{l}\text { Big or small measuring tool of a company } \\
\text { (Nasir et al., 2014) }\end{array}$ & $\begin{array}{l}\text { Ln (Total Assets) } \\
\text { (Nasir et al. (2014) }\end{array}$ \\
\hline Profitability (ROA) & $\begin{array}{l}\text { The ability of company to obtain profits } \\
\text { (Kasmir, 2015) }\end{array}$ & $\begin{array}{c}\text { Net Profit After Tax } \\
\text { Total Asset } \\
\text { (Murhadi, 2015) }\end{array}$ \\
\hline Leverage (DER) & $\begin{array}{l}\text { How much corporate activities financed by } \\
\text { loans (Kasmir, 2015) }\end{array}$ & $\begin{array}{c}\text { Total Debt } \\
\text { Total Equity } \\
\text { (Murhadi, 2015) }\end{array}$ \\
\hline Liquidity (CR) & $\begin{array}{l}\text { Corporate expertise in undertaking payment of } \\
\text { debts that are past due (Kasmir, 2015) }\end{array}$ & $\begin{array}{l}\text { Current Asset } \\
\text { Current Liabilities } \\
\text { (Kasmir, 2015) }\end{array}$ \\
\hline $\begin{array}{l}\text { Corporate activities } \\
\text { (TATO) }\end{array}$ & $\begin{array}{l}\text { Expertise on the use of company assets that } \\
\text { must be effective (Kasmir, 2015) }\end{array}$ & $\frac{\text { Sales }}{\text { Total Assets }}$ \\
\hline $\begin{array}{l}\text { Board of Directors } \\
\text { (DD) }\end{array}$ & $\begin{array}{l}\text { The segment that has the maximum obligation } \\
\text { to the management of company and to be } \\
\text { a representative of the company inside and } \\
\text { outside the court, in accordance with the laws } \\
\text { and regulations (KKNG, 2006) }\end{array}$ & $\begin{array}{l}\sum \text { board of directors meeting in one period } \\
\text { (Idah, 2013) }\end{array}$ \\
\hline $\begin{array}{l}\text { Independent } \\
\text { Commissioner (KI) }\end{array}$ & $\begin{array}{l}\text { Commissioners who are not sourced from } \\
\text { factions that carry business ties and family } \\
\text { with controlling shareholders, directors, other } \\
\text { commissioners, and companies (KNKG, 2006) }\end{array}$ & 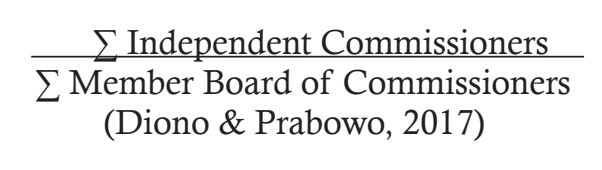 \\
\hline $\begin{array}{l}\text { Audit Committee } \\
\text { (KOMDIT) }\end{array}$ & $\begin{array}{l}\text { Committees created by commissioners to help } \\
\text { carry out their work. (POJK, 2014) }\end{array}$ & $\begin{array}{c}\begin{array}{c}\sum \text { Audit committee meetings in one period } \\
\text { (Sari \& Marsono, 2013) }\end{array} \\
\end{array}$ \\
\hline
\end{tabular}
Source: Various references, 2019

Table 3. Results of Descriptive Statistics Analysis

\begin{tabular}{lrrrrr}
\hline & $\mathrm{N}$ & Minimum & Maximum & Mean & Std. Deviation \\
\hline SR & 85 & 0.10 & 0.95 & 0.3559 & 0.19949 \\
SIZE & 85 & 12.35 & 16.34 & 13.4802 & 0.55740 \\
ROA & 85 & -0.06 & 0.45 & 0.0799 & 0.10348 \\
DER & 85 & 0.00 & 3.56 & 1.1912 & 0.83447 \\
CR & 85 & 0.16 & 2.18 & 0.8054 & 0.50268 \\
TATO & 85 & 0.01 & 2.42 & 0.7249 & 0.48724 \\
DD & 85 & 3.00 & 82.00 & 34.8471 & 16.73498 \\
KI & 85 & 0.17 & 0.80 & 0.3779 & 0.11663 \\
KOMDIT & 85 & 4.00 & 44.00 & 12.6941 & 10.68379 \\
Valid N (listwise) & 85 & & & & \\
\hline
\end{tabular}

Source: secondary processed, 2019

The average sustainability report in Table 3 is 0.3559 , which indicates the low sustainability report disclosure of non-financial companies. Standard deviation values for sustainability report, company size, leverage, liquidity, company activities, board of directors, independent commissioners, and audit committee hold fewer standard deviation values than the average, so the research data is homogeneous data. The standard deviation value for the profitability variable is more than the average value which shows that the data deviation from the average is high so the data in the study have high variability.

The classical assumption test results show that the data has normal distributions and is then avoided from multicollinearity, heteroscedesticity, and autocorrelation tests. Data is called normal when the significance value of asymp. Sig (2-tiled) more than a $=0.05$. The normality test in this study reveals an asymp.sig (2-tiled) value of 0.195 , it can be said to be normally distributed. The multicollinearity test in this study can be seen through 
the analysis of tolerance values $<0.10$ or VIF $>10$. The results show a tolerance value $>0.10$ and a VIF value $<10$. The heteroscedasticity test in this study can be said free from heteroscedasticity if the value of sig. (2-tailed) using absolute Ut as the dependent variable is more than $\mathrm{a}=0.05$. The results show that none of the independent variables statistically having significant effect on the $\mathrm{Ab}$ solute Ut value as the dependent variable meaning the regression model is free from heteroscedasticity.

The autocorrelation test in the study is described by the DW (Durbin-Watson) value which is higher than the upper margin $(\mathrm{du})$ then less than 4-du. The autocorrelation result shows that the DW value of 2.092 is more than the upper margin (du) of 1.714 and less than the 4-du (4-1.714) of 2,286 so that it could be said that the regression model free from autocorrelation. The coefficient of determination (adjusted $\mathrm{R}^{2}$ ) is 0.23 . This means that as much as $23 \%$ of the sustainability report variable can be described by the independent variables in this study namely company size, profitability, leverage, liquidity, company activities, board of directors, independent commissioners, and audit committee. The regression test equation can be seen in Equation 2 then the results of the hypothesis test are seen in Table 3 . The results of the hypothesis testing can be seen in Table 4 .

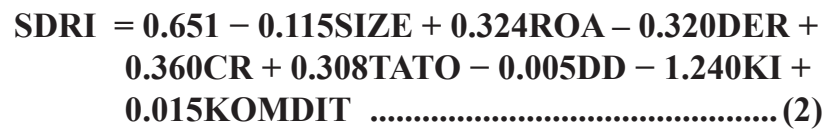

\section{The Effect of Company Size on Sustainability Report Disclosures}

Company size is not able to affect the sustainability report disclosure. The result is not in line with legitimacy theory which states that the larger the company, the higher the disclosure of sustainability report. This can be triggered due to large companies look increasingly vulnerable to political attacks, so that the company's response to this political action is not to be the subject of attention to the impact of important facts delivered by the company (Sari \& Marsono, 2013).

In addition, there are no clear regulations related to corporate obligation to report corporate social responsibility, the disclosure of sustainability reports is more based on the company's ambition and mission in gaining profits. Research data indicates there are companies with high total assets but low sustainability report disclosures, namely PT XL Axiata in 2014 which has a total asset of Rp.63,706,488,000,000.00 with the disclosure of sustainability reports only 12 disclosure items. The research result is supported by Dilling (2010), Nasir et al. (2014), Sari \& Marsono (2013).

\section{Profitability on Sustainability Report Disclosures}

Profitability is not able to have effect on the sustainability report disclosure. The result of the study is not in line with stakeholder theory which explains high profitability in the company can encourage the increase in the extent of information delivered. This can be triggered due to the disclosure of sustainability reports require huge costs but the benefits are not directly received by the company (Saputro et al. 2013).

In addition, according to signalling theory, high profitability is an achievement for the company because it has advantages in obtaining profits. Thus, the company wants this achievement to be pleasant news and spotlight for stakeholders, especially investors and creditors. However, the existence of information implicit in the sustainability report can divert stakeholder attention. The facts of social responsibility become increasingly highlighted rather than high profitability, resulting in low social responsibility delivered by the company. The result of this study is supported by Yi \& Yu (2010), O’Donovan (2012) and Isa (2014).

\section{The Effect of Leverage on Sustainability Report Disclosure}

Leverage has a negative effect on the disclosure of sustainability reports. This is in line with stakeholder theory which states that high leverage causes companies

Table 4. Summary of Hypothesis Test Results

\begin{tabular}{ccccccc}
\hline No & \multicolumn{1}{c}{ Hypothesis } & B & Sig. & $\alpha$ & Results \\
\hline 1 & $\mathrm{H}_{1}:$ & $\begin{array}{l}\text { Company size has a positive effect on sustainability report } \\
\text { disclosure. }\end{array}$ \\
2 & $\mathrm{H}_{2}: \begin{array}{l}\text { Profitability has a positive effect on sustainability report } \\
\text { disclosure. }\end{array}$ & 0.324 & 0.719 & 0.05 & Rejected \\
3 & $\mathrm{H}_{3}: \begin{array}{l}\text { Leverage has a negative effect on sustainability report } \\
\text { disclosure. }\end{array}$ & 0.320 & 0.000 & 0.05 & Accepted \\
4 & $\mathrm{H}_{4}: \begin{array}{l}\text { Liquidity has a positive effect on sustainability report } \\
\text { disclosure. }\end{array}$ & 0.360 & 0.006 & 0.05 & Accepted \\
5 & $\mathrm{H}_{5}: \begin{array}{l}\text { Corporate activities have a positive effect on sustainability } \\
\text { report disclosure. }\end{array}$ & 0.308 & 0.157 & 0.05 & Rejected \\
6 & $\mathrm{H}_{6}: \begin{array}{l}\text { Board of directors has a positive effect on sustainability report } \\
\text { disclosure. }\end{array}$ & -0.005 & 0.216 & 0.05 & Rejected \\
7 & $\mathrm{H}_{7}: \begin{array}{l}\text { Independent commissioners have a positive effect on } \\
\text { sustainability report disclosure. } \\
8\end{array}$ & $\mathrm{H}_{8}: \begin{array}{l}\text { Audit committee has a positive effect on sustainability report } \\
\text { disclosure. }\end{array}$ & 0.150 & 0.013 & 0.05 & Accepted \\
\hline
\end{tabular}


try to avoid the target of debt holders, namely through the reduction of additional information disclosed, including sustainability reports. Companies that have high leverage will depend on the support of creditors, so company management tries to report a lot of profit so that creditors believe that the company is able to pay interest as well as the principal instalments. This causes companies to tend to prioritize loan repayments rather than make voluntary disclosures including disclosure of sustainability reports that have a large budget. The result of the study is supported by Nasir et al. (2014) and Artiach et al. (2010).

\section{The Effect of Liquidity on Sustainability Report Disclosure}

Liquidity has a positive effect on the disclosure of sustainability reports. In accordance with stakeholder theory, a company with a high level of liquidity means it has a superior financial situation that encourages wider disclosure of information for its stakeholders. It aims to form a positive image that is closely related to the company that can show that the company is credible. One effort to increase trust and positive image that already exists through the publication of information related to corporate social responsibility in the form of sustainability reports. The research result is supported by Saputro et al. (2013) and Syed \& Butt (2017).

\section{The Effect of Company Activity on Sustainability Report Disclosure}

Company activities do not affect the sustainability report disclosure. This is not in line with stakeholder theory which conveys that companies with high activity ratio have more ability to convey broader information. This can arise because even though the company has efficiency in managing its assets, it is not certain that the management of assets is used for the implementation of corporate social responsibility. Or it can be said that the efficiency of corporate active management is used for other performances, which are considered more profitable for the company. In addition, management does not consider sustainability report disclosure important because there are no clear regulations can also reduce the disclosure of sustainability reports. The result of this study is supported by Idah (2013), Giannarakis (2014), and Sinaga \& Fachrurrozie (2017).

\section{The Effect of Board of Directors on Sustainability Report Disclosure}

The number of directors meetings does not affect the level of sustainability report disclosure. This is not in accordance with stakeholder theory which states that communication and coordination created through board of directors meetings will encourage the creation of GCG so as to encourage sustainability report disclosure. Table 3 shows the average meeting of the board of directors is 34 times, which means more than the minimum amount set that is 12 times. This can be indicated by the low awareness of companies in implementing
GCG, companies implementing GCG only to comply with regulations not because of necessity. Thus, the frequency of the directors' meeting does not describe a conversation that discusses social responsibility, but instead discusses other company performances. The result of this study is supported Dilling (2010), Sari \& Marsono (2013), Isa (2016), and Bhatia \& Tuli (2016).

\section{The Effect of the Independent Commissioner on Sustainability Report Disclosure}

Independent commissioners are not able to influence the disclosure of sustainability reports. The result is not in line with agency theory which states that the existence of an independent commissioner can drive the sustainability report disclosure. One of the reasons is that the independent commissioner has not yet carried out his duties and functions fully. Table 3 shows the average independent commissioner is $37 \%$, which means more than the minimum amount set that is $30 \%$. Even though there is an independent commissioner, but if the independent commissioner does not have time for the company due to other activities, then the existence of the independent commissioner is not effective. In addition, decision making at the board of commissioners level, including the decision to disclose the sustainability report is not only influenced by the existence of independent commissioners who empower the supervisory function of the board of commissioners, but also is influenced by the quality of the members themselves. The result of this study is supported by Shamil et al. (2012), Bhatia \& Tuli (2016), and Sinaga \& Fachrurrozie (2017).

\section{The Effect of Audit Committee on Sustainability Report Disclosures}

Audit committee has a positive effect on the disclosure of sustainability reports. According to agency theory, the more frequently the audit committee holds meetings, the greater the supervision and evaluation carried out by the audit committee, including gathering opinions and knowledge from members that can increase the disclosure of sustainability reports. In-depth supervision of the audit committee is able to encourage the fulfilment of GCG principles. A qualified audit committee can understand the importance of the information delivered and the needs of stakeholders. Thus, the audit committee discussion can move management to carry out disclosure of sustainability reports into a way of communication with stakeholders. The results of this study are supported Sari \& Marsono (2013) and Michelon \& Parbonetti (2012).

\section{CONCLUSIONS}

This study examines empirical studies of the effect of company size, profitability, leverage, liquidity, company activities, board of directors, independent commissioners, and audit committee to the disclosure of sustainability reports. The results show the average sustainability report in non-financial companies in 2013-2017 disclosed relatively low. In addition, it is 
found that liquidity ratio and audit committee have positive effect on sustainability report disclosures, as well as leverage being able to negatively impact sustainability report disclosures. This shows that leverage, liquidity, and audit committee variables can give important characteristics in the disclosure of the sustainability report. Suggestion for the next researcher is to pay more attention to the calculation of corporate activity ratio, whether using net sales or gross sales. It is feared the use of calculations which is not the same in one study, there are those that use gross sales and there are those that use net sales, so that it will affect the value of the activity ratio that causes the research results are not representative.

\section{REFERENCES}

Artiach, T., Lee, D., Nelson, D., \& Walker, J. (2010). The determinants of corporate sustainability performance. Accounting \& Finance, 50(1), 31-51.

Bhatia, A., \& Tuli, S. (2015). Sustainability disclosure practices: a study of selected Chinese companies. Management and Labour Studies, 40(3-4), 268-283. https://doi org $/ 10.1177 / 0258042 X 15624994$

Branco, M. C., Delgado, C., Gomes, S. F., \& Eugénio, T. C. P. (2014). Factors influencing the assurance of sustainability reports in the context of the economic crisis in Portugal. Managerial Auditing Journal, 29(3), 237-252. https://doi.org/10.1108/MAJ-07-2013-0905

Burgwal, D. Van De, \& Vieira, R. J. O. (2014). Environmental Disclosure Determinants in Dutch Listed Companies. Revista Contabilidade \& Finanças, 25(64), 60-78. Retrieved from http://www.scielo.br/pdf/rcf/v25n64/ en_v25n64a06.pdf

Dilling, P. F. (2010). Sustainability Reporting In A Global Context: What Are The Characteristics Of Corporations That Provide High Quality Sustainability Reports An Empirical Analysis. International Business \& Economics Research Journal (IBER), 9(1). https://doi. org/10.19030/iber.v9i1.505

Diono, H., \& Prabowo, T. J. W. (2017). Analisis Pengaruh Mekanisme Corporate Governance, Porfitabilitas, dan Ukuran Perusahaan Terhadap Tingkat Pengungkapan Sustainibility Report. Diponegoro Journal of Accounting, 6(3), 615-624.

O'Donovan, G. (2002). Environmental disclosures in the annual report: Extending the applicability and predictive power of legitimacy theory. Accounting, Auditing \& Accountability Journal, 15(3), 344-371. https://doi. org/10.1108/09513570210435870

Eisenhardt, K. M. (1989). Building theories from case study research. Academy of Management Review, 14(4), 532-550.

Elkington, J. (1997). Canibals with Forks: TheTriple Bottom Line of 21st Centaury Business. Gabriola, Canada: New Society Publishers.

Ferrão, J., Curto, J. D., \& Gama, A. P. (2016). Low-leverage policy dynamics: an empirical analysis. Review of Accounting and Finance, 15(4), 463-483.

Ghozali, I., \& Chariri, A. (2007). Teori Akuntansi. Semarang: Badan Penerbit Universitas Diponegoro.

Giannarakis, G. (2014). The determinants influencing the extent of CSR disclosure. International Journal of Law and Management, 56(5), 393-416.

Global Reporting Initiative. (2016). Pedoman Pelaporan Keberlanjutan GRI Standards. https://www.globalreporting. org/standards/gri-standards-translations/gri-standards-bahasa-indonesia-translations-download-center/. (Diunduh 9 Februari 2019)

Idah. (2013). Corporate Governance dan Karakteristik Peru- sahaan dalam Pengungkapan Sustainability Report. Accounting Analysis Journal, 2(3), 361-369. https://doi. org/ISSN 2252-6765

Isa, M. A. (2014). Sustainability Reporting among Nigeria Food and Beverages Firms. International Journal of Agriculture and Economic Development, 2(1). 1-9. Malaysia: Universiti Utara Malaysia.

Kasmir. (2015). Analisis Laporan Keuangan. Jakarta : Rajawali Press.

KNKG. (2006). Pedoman Umum Corporate Governance Indonesia. Liu, X., \& Anbumozhi, V. (2009). Determinant factors of corporate environmental information disclosure: an empirical study of Chinese listed companies. Journal of Cleaner Production, 17(6), 593-600. https://doi. org/10.1016/j.jclepro.2008.10.001

Michelon, G., \& Parbonetti, A. (2012). The Effect of Corporate Governance on Sustainability Disclosure. Journal of Management and Governance, 16(3), 477-509. https:// doi.org/10.1007/s10997-010-9160-3.

Murhadi, W. R. (2015). Analisis Laporan Keuangan Proyeksi dan Valuasi Saham. Jakarta: Salemba Empat.

Nasir, A., Ilham, E., \& Utara, V. I. (2014). Analisis pengaruh good corporate governance terhadap kualitas sustainability report (studi empiris pada perusahaan di indonesia periode tahun 2011-2012). Jurnal Ekonomi, 22(1), 6584. https://doi.org/10.1017/CBO9781107415324.004

Nazari, J.A., Herremans, I.M. and Warsame, H.A. (2015). Sustainability reporting: external motivators and internal facilitators. Corporate Governance, 15(3), 375-390. https://doi.org/10.1108/CG-01-2014-0003

Peraturan Otoritas Jasa Keuangan Nomor 55/POJK.04/2015. Tentang Pembentukan dan Pedoman Pelaksanaan Kerja Komite Audit. (Online) www.ojk.go.id/regulasi/peraturan-ojk/POJK-Nomor55.POJK.04.2015/. Diakses pada 16 Februari 2019.

Saputro, D.A, Agustina, L., \& Fachrurrozie. (2013). Pengaruh Kinerja Keuangan Terhadap Pengungkapan Sustainability Report Perusahaan Di Bursa Efek Indonesia. Accounting Analysis Journal, 2(4), 480-488.

Sari, M., P., Y., \& Marsono. (2013). Pengaruh Kinerja Keuangan, Ukuran Perusahaan dan Corporate Governance Terhadap Pengungkapan Sustainabillitty Report. Diponegoro Journal of Accounting, 2(3), 580-589.

Shamil, M. M., Shaikh, J. M., \& Ho, P. (2012). The influence of board characteristics on sustainability reporting Empirical evidence from Sri Lankan firms. Asian Review of Accounting, 22(2), 78-97 https://doi.org/10.1108/ ARA-09-2013-0060

Sinaga, K. J., \& Fachrurrozie. (2017). The Effect of Profitability, Activity Analysis, Industrial Type and Good Corporate Governance Mechanism on The Disclosure of Sustainability Report. AAJ: Accounting Analysis Journal, 6(3), 347-358.

Suchman, M. C. (1995). and Strategic Managing Legitimacy: Approaches. Journal ofManagement, 20(3), 571-610.

Syed, M. A., \& Butt, S. A. (2017). Financial and non-financial determinants of corporate social responsibility : empirical evidence from Pakistan. Social Responsibility Journal, 13(4), 780-797.

Vitezić, V., Morec, B., \& Tekavcic, M. (2012). Does Financial Performance Have an Impact on Corporate Sustainability and CSR Disclosure - A Case of Croation Companies. Journal of Business Management, 5(2012), 40-47.

Wulanda. (2017). Pengaruh Karakteristik Perusahaan dan Corporate Governance terhadap Publikasi Sustainability Report. JOM Fekon, 4(1), 120-132.

Yi, T. F., \& Yu, C. K. (2010). Research on Sustainability Reporting in Hong Kong. Working Paper. Hongkong: Hong Kong Baptist University. 